\title{
Blackland Tallgrass Prairie Vegetation Dynamics Following Cessation of Herbicide Application
}

\author{
Karen R. Hickman ${ }^{1}$ and Justin D. Derner ${ }^{2}$ \\ Authors are ${ }^{1}$ Associate Professor, Natural Resource Ecology and Management, Oklahoma State \\ University, Stillwater, OK 74078; and ${ }^{2}$ Rangeland Scientist, USDA-ARS, High Plains Grasslands \\ Research Station, Cheyenne, WY 82009.
}

\begin{abstract}
We studied short-term (1-3 years) responses of plant species and functional group abundances, richness, evenness, diversity, and similarity following cessation of 25 years (1972-1997) of herbicide application in a remnant of Blackland Tallgrass Prairie in central Texas. Substantial increases in plant cover from 1998 to 2000 were observed for annual forbs (359\%-900\%), primarily attributable to firewheel (Gaillardia pulchella Foug), but C4 perennial grass cover only marginally increased $(22 \%-23 \%)$. These disproportionate increases elicited a directional compositional change in the plant community with dominance shifting from C4 perennial grasses to annual forbs. Species richness, evenness, and diversity decreased from 1998 to 2000 for May, but increased for June, sampling date. Conservation efforts pertaining to remnants of Blackland Tallgrass Prairie need to be cognizant that dramatic short-term effects on vegetation dynamics will occur following cessation of annual herbicide applications, and that enhancement of perennial forbs may require seeding or transplanting species.
\end{abstract}

\section{Resumen}

Estudiamos las repuestas a corto plazo ( 1 a 3 años) de especies vegetales y la abundancia, riqueza, uniformindad, diversidad y similaridad de grupos funcionales posterior al cese de 25 años de aplicación de herbicidas (1972-1997) en un remanente de las Praderas de Zacates Altos Blackland en la región central de Texas. De 1998 al 2000, se observaron aumentos substanciales de la cobertura de hierbas anuales (359\%-900\%), atribuible principalmente al "firewheel" (Gaillardia pulchella Foug); la cobertura de zacates perennes $\mathrm{C}_{4}$ tuvo solo un incremento marginal (22\%-23\%). Estos aumentos desproporcionados lograron un cambio direccional en la composición de la comunidad vegetal, de una dominancia de zacates perennes $\mathrm{C}_{4}$ a una de hierbas anuales. La riqueza de especies, uniformidad y diversidad de 1998 al 2000 disminuyó en la fecha de muestreo de Mayo, pero se incrementó en la de Junio. Los programas de conservación pertinentes a los remanentes de las Paderas de Zacates Altos Blackland necesitan estar enterados de que después del cese de las aplicaciones anuales de herbicidas ocurrirán dramáticos efectos a corto plazo en la dinámica de la vegetación, y que el aumento de las hierbas perennes puede requerir de la siembra o transplante de especies vegetales.

Key Words: abundance, evenness, functional groups, Shannon species diversity, Sørenson’s similarity index, species richness

\section{INTRODUCTION}

The Blackland Tallgrass Prairie, the southernmost extension of the True Prairie, originally encompassed approximately 4.2 million ha extending as a narrow north-south band in central Texas (Dodd 1968). About $95 \%$ of this land area has been cultivated, with the remaining areas existing as small $(<10 \mathrm{ha})$ remnants, primarily managed for hay production (Riskind and Collins 1975; Diamond and Smeins 1993). Common management practices include annual broadleaf herbicide (e.g., 2,4-D) application in midspring to increase $\mathrm{C} 4$ perennial grass contribution to hay yield. Annual herbicide application has likely modified vegetation composition and plant diversity patterns, and also may have substantially altered ecosystem structure and function (e.g., Chapin et al. 1997).

The United States Department of Agriculture (USDA) prohibits discrimination in all its programs and activities on the basis of race, color, national origin, gender, religion, age, disability, political beliefs, sexual orientation, and marital or family status.

Correspondence: Karen R. Hickman, 167 Ag Hall, Oklahoma State University, Stillwater, OK 74078. Email: karen.hickman@okstate.edu

Manuscript received 21 May 2005; manuscript accepted 29 December 2006.
The Blackland Tallgrass Prairie is highly endangered because of previous and continuing human perturbations (Riskind and Collins 1975). Recent conservation efforts have included the purchase of conservation easements or acquisition of remnant prairies. The vast majority of these prairies have a history of herbicide application (Burleson 1993), which generally necessitates a change in management, because an emphasis of conservation efforts is usually the cessation of nonnatural disturbances. Although long-term vegetation change is the primary interest, understanding initial vegetation dynamics following the removal of annual herbicide application may provide valuable insight beneficial to future conservation efforts. To our knowledge, data are lacking on the initial responses of plant communities to cessation of herbicide application in the Blackland Tallgrass Prairie.

The 2 primary questions of this research were: 1 ) what are the short-term (1-3 years) vegetation dynamics following cessation of 25 years of annual herbicide application in Blackland Tallgrass Prairie, and 2) what are the similarities/ differences in vegetation dynamics between remnants that have had herbicide applications recently terminated and remnants without any prior history of herbicide applications? 


\section{METHODS}

Two remnants in the Blackland Tallgrass Prairie with contrasting histories of herbicide use were selected based on their close proximity (within $2 \mathrm{~km}$ ), similar size ( $3 \mathrm{ha}$ ), soils (Heiden soil series; fine, smectitic thermic Udic Haplusterts), slope $(1 \%-$ $3 \%$ ), long-term use (hay production), and dominant plant species. Both remnants are surrounded by croplands and permanent pastures. One remnant has a 25-year history (1972$1997)$ of annual herbicide $\left(2,4-\mathrm{D}\right.$ at $0.28 \mathrm{~kg}$ a.i. $\cdot \mathrm{ha}^{-1}$ ) application, and is located on the United States Department of Agriculture Agricultural Research Service Grassland, Soil and Water Research Laboratory near Riesel, Texas (lat $31^{\circ} 28^{\prime} \mathrm{N}$; long $\left.96^{\circ} 52^{\prime} \mathrm{W}\right)$. Since 1998 , this remnant has not received any herbicide treatment. The other remnant, owned by the Native Prairie Association of Texas, has no history of herbicide use (Paul Mezynski, personal communication, May 1997). Annual precipitation for 1998, 1999, and 2000 was 924, 502, and $1106 \mathrm{~mm}$, respectively, with 1999 the second driest year in the long-term (63-year) record (annual average $896 \mathrm{~mm}$ ).

Plant species composition in both remnants was assessed in mid-May and mid-June in 1998, 1999, and 2000 in 10, $1 \times 1 \mathrm{~m}$ quadrats systematically located along each of 5, 75-m-long randomly located transects. Plants within quadrats were identified to species (if possible) or genus and assigned to a functional group: C4 perennial grass, C3 annual grass, C3 perennial grass, perennial forb, annual forb, forb (if unable to identify longevity), or subshrub. Nomenclature follows Diggs et al. (1999). Species composition was determined by visually estimating each plant species' cover with the use of 7 cover classes modified from Daubenmire (1959): $1=<1 \%$ cover; $2=$ $1 \%-5 \% ; 3=6 \%-25 \% ; \quad 4=26 \%-50 \% ; \quad 5=51 \%-75 \%$; $6=76 \%-95 \%$; and $7=96 \%-100 \%$. Midpoints of cover classes were used in data analysis for each species (Towne et al. 2005). Plant species richness, evenness of species cover (Pielou's J index), species relative cover, and Shannon species diversity (Magurran 1988) were calculated. We summed individual species cover values by functional group to determine functional group cover (Howe 1995; Wilson and Tilman 2002), and these values were used to calculate functional group diversity with the use of Shannon diversity $\left(H^{\prime}=-\right.$ $\Sigma\left[p_{i} \cdot \ln p_{i}\right]$, where $p_{i}=$ proportional contribution of functional group $i$ to the plant community; Magurran 1988). Sørensen's similarity index (Magurran 1988) was calculated for a qualitative assessment for each sampling period.

Neither of the herbicide treatments were replicated, but this is a unique situation with both remnants within close proximity, having the same soil series, similar size, similar dominant plant species, and known long-term histories of management. Inferences from our findings, however, are specific to our experimental location and treatments. Further experimentation is required to determine applicability of results to a wider geographic area.

\section{RESULTS}

\section{Previously Herbicided Remnant}

Total cover of plant species increased 2.1-fold (May sampling) and 2.5-fold (June sampling) from 1998 to 2000 (Table 1). Cover of all functional groups increased, with the exception of
C3 perennial grasses in the May sampling (-27\%). The largest increases in cover were observed for annual forbs $(359 \%$ in May, $900 \%$ in June), perennial forbs $(76 \%, 284 \%)$ and subshrubs $(184 \%, 71 \%)$. C4 perennial grass cover increased only $22 \%$ and $23 \%$ for May and June sampling, respectively. A directional composition shift in the plant community was observed over the 3 years, as annual forbs became the dominant functional group. This shift was primarily attributable to the large increase in firewheel (Gaillardia pulchella Foug). C4 perennial grasses were the dominant functional group in 1998 with 29\% relative cover in May and 58\% in June, but these values declined to $17 \%$ in May 2000 and 29\% in June 2000. Composition of other functional groups was largely unchanged with the notable exception of the decrease in C3 perennial grasses in May from 13\% in 1998 to 5\% in 2000.

Responses of species and functional group richness, evenness, and diversity differed with sampling date (Table 2). Species richness, evenness, and diversity decreased from 1998 to 2000 in the May sampling, but these attributes increased for the June sampling. Functional group richness, evenness, and diversity did not differ between May 1998 and 2000, whereas only evenness and diversity increased in the June sampling.

\section{Comparison Between Previously and Nonherbicided Remnants}

Total cover of species was similar between the 2 remnants for the initial May 1998 sampling and slightly higher in the nonherbicided remnant in the June 1998 sampling (Table 1). Consistently greater total cover of species was observed in the nonherbicided remnant for all samplings in 1999 and 2000. Cover of C4 and C3 perennial grasses were similar between the remnants in May 1998 , but cover of both was greater in the nonherbicided than the previously herbicided remnant in May 2000. Little bluestem (Schizachyrium scoparium [Michx.] Nash) and Texas wintergrass (Nassella leucotrichia [Trin. and Rupr.] Barkworth) were the most prominent C4 and C3 perennial grasses, respectively (Table 1). Cover of perennial forbs was consistently greater in the nonherbicided remnant across all sampling dates; opposite findings were observed for annual forbs. Composition of the nonherbicided remnant was largely unchanged from 1998 to 2000. Perennial forbs and C4 perennial grasses continued to be the dominant functional groups at all sampling dates.

Changes were observed in the relationship between remnants and species richness, evenness, and diversity for the May, but not the June, samplings (Table 2). Functional group evenness, initially higher in the previously herbicided remnant in May 1998, did not differ in May 2000. Functional group diversity was initially higher in the nonherbicided remnant in May 1998, but did not differ in May 2000. Sørensen's similarity index for species and functional groups was unchanged for both the May and June sampling dates. Comparison of the similarity index values for species and functional groups indicates less similarity in species $(0.65$ and 0.75$)$ between the 2 remnants than for plant functional groups (0.92-1.00).

\section{DISCUSSION}

We observed substantial short-term (3 years) vegetation change in our May and June samplings following the cessation of 
Table 1. Total cover of species within functional groups and percent composition by functional group with the use of species cover values. NH (nonherbicided) denotes prairie remnant without a history of herbicide use, $\mathrm{PH}$ (previously herbicided) denotes prairie remnant with a 25-year history of annual herbicide application and then cessation of this practice in 1998. Nomenclature from Diggs et al. (1999).

\begin{tabular}{|c|c|c|c|c|c|c|c|c|c|c|c|c|c|}
\hline \multirow[b]{2}{*}{ Functional group } & \multirow[b]{2}{*}{ Species } & \multicolumn{2}{|c|}{ May 1998} & \multicolumn{2}{|c|}{ June 1998} & \multicolumn{2}{|c|}{ May 1999} & \multicolumn{2}{|c|}{ June 1999} & \multicolumn{2}{|c|}{ May 2000} & \multicolumn{2}{|c|}{ June 2000} \\
\hline & & $\mathrm{NH}$ & $\mathrm{PH}$ & $\mathrm{NH}$ & $\mathrm{PH}$ & $\mathrm{NH}$ & $\mathrm{PH}$ & $\mathrm{NH}$ & $\mathrm{PH}$ & $\mathrm{NH}$ & $\mathrm{PH}$ & $\mathrm{NH}$ & $\mathrm{PH}$ \\
\hline \multirow[t]{5}{*}{ C4 perennial grasses } & & 32.2 & 34.7 & 59.9 & 70.0 & 41.8 & 25.1 & 77.4 & 57.9 & 75.3 & 42.5 & 112.2 & 86.1 \\
\hline & Schizachyrium scoparium (Michx.) Nash & 21.6 & 22.1 & 37.3 & 38.5 & 27.8 & 18.9 & 42.1 & 33.4 & 42.1 & 17.9 & 53.5 & 33.9 \\
\hline & Sorghastrum nutans (L.) Nash & 3.7 & 5.6 & 8.9 & 17.3 & 10.5 & 4.1 & 22.0 & 11.1 & 11.9 & 10.1 & 19.4 & 16.9 \\
\hline & Andropogon gerardii Vitman & 6.3 & 1.0 & 9.8 & 1.3 & 2.9 & 0.4 & 8.2 & 2.8 & 8.4 & 1.0 & 13.6 & 4.2 \\
\hline & Other & 0.6 & 6.0 & 4.0 & 13.0 & 0.5 & 1.6 & 5.2 & 10.6 & 12.9 & 13.5 & 25.7 & 31.1 \\
\hline \multirow[t]{4}{*}{ C3 perennial grasses } & & 10.3 & 15.9 & 6.8 & 9.4 & 22.6 & 19.1 & 25.0 & 22.2 & 43.0 & 11.6 & 41.3 & 31.2 \\
\hline & Carex spp. & 2.3 & 1.3 & 2.5 & 1.0 & 2.5 & 2.2 & 4.7 & 5.3 & 10.6 & 4.2 & 9.8 & 6.7 \\
\hline & $\begin{array}{l}\text { Nassella leucotricha [Trin. and Rupr.] } \\
\text { Barkworth }\end{array}$ & 7.9 & 14.2 & 4.3 & 8.3 & 19.7 & 16.8 & 20.2 & 16.9 & 29.1 & 7.5 & 30.0 & 22.6 \\
\hline & Other & 0.1 & 0.4 & 0.0 & 0.0 & 0.4 & 0.1 & 0.1 & 0.0 & 3.3 & 0.2 & 1.6 & 1.9 \\
\hline \multirow[t]{4}{*}{ C3 annual grasses } & & 6.4 & 6.7 & 0.0 & 0.0 & 15.4 & 8.6 & 0.0 & 0.0 & 13.8 & 7.5 & 8.2 & 0.0 \\
\hline & Bromus tectorum L. & 0.0 & 0.3 & 0.0 & 0.0 & 8.0 & 0.2 & 0.0 & 0.0 & 8.2 & 0.4 & 0.0 & 0.0 \\
\hline & Limnodea arkansana (Nutt.) L. H. Dewey & 0.6 & 5.1 & 0.0 & 0.0 & 7.3 & 8.4 & 0.0 & 0.0 & 5.6 & 7.1 & 0.0 & 0.0 \\
\hline & Other & 5.8 & 1.3 & 0.0 & 0.0 & 0.1 & 0.0 & 0.0 & 0.0 & 0.0 & 0.0 & 8.2 & 0.0 \\
\hline \multirow[t]{8}{*}{ Perennial forbs } & & 56.9 & 28.7 & 55.9 & 14.8 & 85.8 & 38.2 & 86.3 & 36.7 & 125.7 & 50.5 & 117.8 & 56.8 \\
\hline & Aster ericoides $\mathrm{L}$. & 6.7 & 0.0 & 12.2 & 0.0 & 8.8 & 0.0 & 12.5 & 0.0 & 9.9 & 0.0 & 18.3 & 0.0 \\
\hline & Cacalia spp. & 12.2 & 6.0 & 3.2 & 0.4 & 18.3 & 6.8 & 7.9 & 4.7 & 25.9 & 7.9 & 14.7 & 10.4 \\
\hline & Ruellia humilus Nutt. & 7.5 & 0.0 & 9.3 & 0.0 & 10.6 & 0.0 & 12.6 & 0.4 & 12.6 & 0.1 & 14.6 & 0.1 \\
\hline & Ruellia nudiflora (Engelm. \& A. Gray) Urb. & 5.7 & 0.0 & 6.9 & 0.0 & 9.8 & 0.1 & 13.7 & 0.3 & 12.9 & 0.2 & 19.0 & 0.1 \\
\hline & Salvia azurea Michx. ex Lam. & 7.3 & 0.2 & 6.1 & 0.0 & 4.9 & 0.0 & 7.8 & 0.1 & 9.4 & 0.0 & 12.9 & 0.0 \\
\hline & Schrankia spp. & 5.6 & 4.5 & 8.8 & 5.2 & 8.8 & 6.0 & 10.1 & 11.6 & 14.9 & 10.5 & 13.5 & 11.1 \\
\hline & Other & 12.0 & 18.1 & 9.4 & 9.1 & 24.4 & 25.3 & 21.7 & 19.6 & 40.1 & 31.9 & 24.9 & 35.1 \\
\hline \multirow[t]{5}{*}{ Annual forbs } & & 2.6 & 23.0 & 0.1 & 9.0 & 21.0 & 50.5 & 6.7 & 47.2 & 13.9 & 105.6 & 3.3 & 90.3 \\
\hline & Centaurea americana Nutt. & 0.0 & 2.3 & 0.0 & 1.2 & 1.3 & 2.3 & 2.1 & 6.7 & 1.5 & 8.2 & 0.6 & 9.1 \\
\hline & Gaillardia pulchella Foug & 0.0 & 4.9 & 0.0 & 5.7 & 0.0 & 37.1 & 0.0 & 35.3 & 0.6 & 78.6 & 0.0 & 66.8 \\
\hline & Hedyotis nigricans (Lam.) Fosberg & 0.0 & 1.4 & 0.0 & 1.8 & 0.0 & 2.8 & 0.0 & 3.9 & 0.0 & 6.8 & 0.0 & 7.6 \\
\hline & Other & 2.6 & 14.5 & 0.1 & 0.4 & 19.6 & 8.3 & 4.7 & 1.4 & 11.7 & 12.1 & 2.7 & 6.8 \\
\hline Forbs & & 0.3 & 0.9 & 0.4 & 0.7 & 2.9 & 2.6 & 4.6 & 2.4 & 7.7 & 3.2 & 5.7 & 4.3 \\
\hline Subshrubs & Acacia angustissima (Mill.) Kuntze & 12.6 & 10.1 & 16.5 & 18.1 & 23.9 & 13.8 & 22.6 & 17.9 & 28.4 & 28.7 & 32.5 & 31.2 \\
\hline Sum & & 121.3 & 121.6 & 139.6 & 120.3 & 213.1 & 157.9 & 222.7 & 182.2 & 307.9 & 250.2 & 320.9 & 299.1 \\
\hline
\end{tabular}

C4 perennial grasses

C3 perennial grasses

C3 annual grasses

Perennial forbs

Annual forbs

Forbs

Subshrubs

Percent composition by functional group with the use of cover values

\begin{tabular}{rrrrrrrrrrrr}
\hline 26.5 & 28.9 & 42.9 & 57.4 & 19.6 & 15.9 & 34.8 & 31.4 & 24.5 & 17.0 & 35.0 & 28.7 \\
8.5 & 13.3 & 4.9 & 7.7 & 10.6 & 12.1 & 11.2 & 12.0 & 14.0 & 4.7 & 12.9 & 10.4 \\
5.3 & 5.6 & 0.0 & 0.0 & 7.2 & 5.5 & 0.0 & 0.0 & 4.5 & 3.0 & 2.5 & 0.0 \\
46.9 & 23.6 & 40.0 & 12.1 & 40.2 & 24.2 & 38.8 & 19.9 & 40.8 & 20.2 & 36.7 & 18.9 \\
2.2 & 19.2 & 0.1 & 7.4 & 9.8 & 32.0 & 3.0 & 25.6 & 4.5 & 42.3 & 1.0 & 30.1 \\
0.2 & 0.7 & 0.3 & 0.6 & 1.3 & 1.7 & 2.1 & 1.3 & 2.5 & 1.3 & 1.8 & 1.4 \\
10.4 & 18.9 & 11.8 & 14.8 & 11.2 & 8.7 & 10.2 & 9.7 & 9.2 & 11.5 & 10.1 & 10.4 \\
\hline
\end{tabular}

annual herbicide application in a Blackland Tallgrass Prairie remnant after a 25-year history. All plant functional groups responded with increases in cover, except for C3 perennial grasses in the May sampling. These responses differed between functional groups, however, with the largest increases occurring for annual and perennial forbs and subshrubs, whereas C4 perennial grasses only marginally increased. These disproportionate increases elicited a directional composition shift in the plant community with $\mathrm{C} 4$ perennial grass dominance being displaced by annual forb dominance.

Functional group richness, evenness, and diversity did not change for the May samplings, but in June samplings, evenness and diversity increased. Comparison of species composition from the year prior to initiation of annual herbicide application (1971; Smeins 1972) with the year following removal of this perturbation (1998) reveals that little bluestem was the dominant species in both years, but forbs replaced indiangrass (Sorghastrum nutans [L.] Nash) as the second most prevalent species. Interestingly, dominance of little bluestem dramatically declined in 1999 and 2000 as the annual forb firewheel became dominant, suggesting that firewheel rapidly filled open niches created by the termination of annual herbicide application, likely magnified by 1999 drought conditions. These results clearly indicate that conservation efforts targeting preserving remnants of the Blackland Tallgrass Prairie 
Table 2. Mean ( $\pm 1 \mathrm{SE}$ ) indices of species and functional group attributes $\left(\mathrm{m}^{-2}\right)$. Nonherbicided denotes prairie remnant without a history of herbicide use, previously herbicided denotes prairie remnant with a 25-year history of annual herbicide application and then cessation of this practice in 1998.

\begin{tabular}{|c|c|c|c|c|c|c|c|}
\hline \multirow[b]{2}{*}{ Attribute } & \multirow[b]{2}{*}{ Remnant } & \multicolumn{3}{|c|}{ May } & \multicolumn{3}{|c|}{ June } \\
\hline & & 1998 & 1999 & 2000 & 1998 & 1999 & 2000 \\
\hline \multicolumn{8}{|l|}{ Species } \\
\hline \multirow[t]{4}{*}{ Richness } & Nonherbicided & 15.6 & 18.8 & 17.7 & 11.1 & 14.0 & 13.9 \\
\hline & & $(0.4)$ & $(0.4)$ & $(0.3)$ & $(0.2)$ & $(0.2)$ & $(0.3)$ \\
\hline & Previously herbicided & 20.4 & 16.0 & 17.1 & 11.3 & 10.4 & 13.5 \\
\hline & & $(0.40)$ & $(0.4)$ & $(0.5)$ & $(0.3)$ & $(0.3)$ & $(0.4)$ \\
\hline \multirow[t]{4}{*}{ Evenness } & Nonherbicided & 0.80 & 0.85 & 0.91 & 0.78 & 0.88 & 0.91 \\
\hline & & $(0.007)$ & $(0.006)$ & $(0.004)$ & $(0.01)$ & $(0.006)$ & $(0.003)$ \\
\hline & Previously herbicided & 0.81 & 0.76 & 0.77 & 0.69 & 0.86 & 0.87 \\
\hline & & $(0.01)$ & $(0.01)$ & $(0.01)$ & $(0.01)$ & $(0.01)$ & $(0.008)$ \\
\hline \multirow[t]{4}{*}{ Diversity } & Nonherbicided & 2.17 & 2.47 & 2.61 & 1.87 & 2.30 & 2.38 \\
\hline & & $(0.04)$ & $(0.03)$ & $(0.05)$ & $(0.03)$ & $(0.03)$ & $(0.02)$ \\
\hline & Previously herbicided & 2.43 & 2.09 & 2.18 & 1.66 & 2.01 & 2.26 \\
\hline & & $(0.03)$ & $(0.03)$ & $(0.02)$ & $(0.04)$ & $(0.03)$ & $(0.02)$ \\
\hline \multirow[t]{2}{*}{ Similarity } & & 0.72 & 0.69 & 0.75 & 0.65 & 0.71 & 0.73 \\
\hline & & $(0.03)$ & $(0.02)$ & $(0.008)$ & $(0.007)$ & $(0.009)$ & $(0.008)$ \\
\hline \multicolumn{8}{|c|}{ Functional group } \\
\hline \multirow[t]{4}{*}{ Richness } & Nonherbicided & 7 & 7 & 7 & 6 & 6 & 7 \\
\hline & & $(0.3)$ & $(0.1)$ & $(0.3)$ & $(0.1)$ & $(0.2)$ & $(0.2)$ \\
\hline & Previously herbicided & 7 & 7 & 7 & 6 & 6 & 6 \\
\hline & & $(0.1)$ & $(0.2)$ & $(0.2)$ & $(0.1)$ & $(0.1)$ & $(0.09)$ \\
\hline \multirow[t]{4}{*}{ Evenness } & Nonherbicided & 0.61 & 0.77 & 0.74 & 0.60 & 0.68 & 0.70 \\
\hline & & $(0.008)$ & $(0.006)$ & $(0.004)$ & $(0.003)$ & $(0.004)$ & $(0.007)$ \\
\hline & Previously herbicided & 0.76 & 0.75 & 0.73 & 0.57 & 0.76 & 0.81 \\
\hline & & $(0.01)$ & $(0.004)$ & $(0.005)$ & $(0.006)$ & $(0.008)$ & $(0.006)$ \\
\hline \multirow[t]{4}{*}{ Diversity } & Nonherbicided & 1.51 & 1.46 & 1.40 & 1.03 & 1.37 & 1.45 \\
\hline & & $(0.03)$ & $(0.02)$ & $(0.03)$ & $(0.03)$ & $(0.02)$ & $(0.02)$ \\
\hline & Previously herbicided & 1.22 & 1.51 & 1.44 & 0.99 & 1.28 & 1.28 \\
\hline & & $(0.03)$ & $(0.03)$ & $(0.02)$ & $(0.02)$ & $(0.03)$ & $(0.02)$ \\
\hline \multirow[t]{2}{*}{ Similarity } & & 1.00 & 0.93 & 1.00 & 0.92 & 0.92 & 0.92 \\
\hline & & $(0.03)$ & $(0.02)$ & $(0.1)$ & $(0.02)$ & $(0.04)$ & $(0.02)$ \\
\hline
\end{tabular}

will need to be cognizant that abrupt changes in management (i.e., termination of annual herbicide application) may substantially affect short-term vegetation composition. Whether these changes are manifested in long-term changes to the plant community, however, remains to be determined.

We observed consistently greater total cover of species in the remnant without a history of herbicide application for all samplings in years 2 and 3. However, in contrast to the directional plant community shift observed in the remnant with a history of herbicide application, the composition of the remnant without a history of herbicide application was largely unchanged over the duration of this investigation. The similarity of vegetation, both from a species and functional group standpoint, revealed no differences between the 2 remnants. Temporal variation in plant community attributes was higher in the remnant with the past history of herbicide application. Seventy-five percent of the plant species observed were present in both remnants, including the dominant perennial grass species. Species not present in both remnants were, in most instances, more subordinate, rare species. An exception was the perennial forb species heath aster (Aster ericoides L.) which was not present in the remnant with a history of annual herbicide application. Because this species is a component of the climax plant community of Blackland Tallgrass Prairie (Diamond and Smeins 1988), conservation efforts focused on preserving the plant diversity of this endangered ecosystem may need to include seeding or transplanting this species to formerly herbicided remnants (Wells et al. 1989).

\section{MANAGEMENT IMPLICATIONS}

Cessation of annual herbicide application in the Blackland Tallgrass Prairie influenced short-term (1-3 years) vegetation dynamics. A pertinent finding for conservation management of these lands is the marginal increase in perennial forb composition following cessation of the herbicide application after a 25-year history. Perennial forb cover remained $<50 \%$ compared to the remnant without a history of herbicide application, suggesting that additional management practices are necessary to increase composition. Seeding or transplanting 
perennial forbs when favorable growing conditions occur may be effective practices to enhance perennial forbs.

\section{ACKNOWLEDGMENTS}

The authors wish to thank Kyle Tiner, Holly Harland, Adrian Lopez, and Brooke Kramer for data collection and entry, 2 anonymous reviewers, and the Associate Editor for their excellent comments on previous drafts of the manuscript. Mr. and Mrs. Paul Mezynski graciously permitted access to their native prairie.

\section{LITERATURE CITED}

BuRLESON, M. F. 1993. The vanished tallgrass prairie: what we have lost, what we have gained. In: M. R. Sharpless and J. C. Yelderman [EDs.]. The Texas Blackland Prairie: Land, history, and culture. Waco, TX: Baylor University Press. p. 281-297.

Chapin, F. S., III, B. H. Walker, R. J. Hobbs, D. U. Hooper, J. H. Lawton, O. E. Sala, and D. TILMAn. 1997. Biotic control over the functioning of ecosystems. Science 277:500-504.

DaubenmiRe, R. 1959. A canopy-coverage method of vegetational analysis. Northwest Science 33:43-64.

Diamond, D. D., and F. E. Smeins. 1988. Gradient analysis of remnant True and Upper Coastal Prairie grasslands of North America. Canadian Journal of Botany 66:2152-2161.
Diamond, D. D., and F. E. Smeins. 1993. The native plant communities of the Blackland Prairie. In: M. R. Sharpless and J. C. Yelderman [EDS.]. The Texas Blackland Prairie: Land, history, and culture. Waco, TX: Baylor University Press. p 66-81.

Diggs, G. M., JR., B. L. Lipscomb, And R. J. O'Kennon. 1999. Shinners \& Mahler's illustrated flora of north central Texas. Fort Worth, TX: Botanical Research Institute of Texas. $1626 \mathrm{p}$.

DodD, J. D. 1968. Grassland associations in North America. In: F. W. Gould [ED.] Grass systematics. New York, NY: McGraw-Hill. p 324-338.

HowE, H. F. 1995. Succession and fire season in experimental prairie plantings. Ecology 76:1917-1925

MagurRan, A. E. 1988. Ecological diversity and its measurement. Princeton, NJ: Princeton University Press. $179 \mathrm{p}$.

Riskind, D. H., And O. B. Collins. 1975. The Blackland Prairie of Texas: conservation of representative climax remnants. In: M. K. Wali [ED.]. Prairie: A multiple view. Grand Forks, ND: University of North Dakota Press. p 361-367.

SmeINS, F. E. 1972. Influence of fire and mowing on vegetation of the Blackland Prairie of Texas. In: L. C. Hulbert [ED.]. Third Midwest Prairie Conference Proceedings. Manhattan, KS. p 4-7.

Towne, E. G., D. C. Hartnett, and R. Cochran. 2005. Vegetation trends in tallgrass prairie from bison and cattle grazing. Ecological Applications 15:1550-1559.

Wells, T. C. E., R. Cox, And A. Frost. 1989. Diversifying grasslands by introducing seed and transplants into existing vegetation. In: G. P. Buckley [ED.]. Biological habitat reconstruction. London, United Kingdom: Belhaven Press. p 283-298.

WiLson, S. D., AND D. TILMAN. 2002. Quadratic variation in old-field species richness along gradients of disturbance and nitrogen. Ecology 83:492-504. 